\title{
Monitoring of Foodborne Hepatitis A virus Outbreaks in the Fresh Foods
}

\author{
K. A. El Dougdoug ${ }^{\#}$, M.A. Nasr-Eldin*, H.S. Esawy*, M.M. Amer* and M.M. Abd \\ Elrhiem* \\ Microbiology Department, Faculty of Agriculture, Ain Shams University, Cairo and \\ *Botany Department, Faculty of Science, Benha University, Benha, Egypt.
}

$\mathbf{H}$ EPATITIS A virus (HAV) is one of the most widespread foodborne pathogens and the cause of viral hepatitis. Fresh foods can be considered as a vector of transmission for HAV when contaminated by spoiled irrigation water or when prepared by infected food handlers. To improve microbiological detection and to increase insights into the contribution of fruit and vegetables to foodborne viral transmission, sensitive and standardized methods are needed. Two outlet drainage water samples from El-Mariotia and El-Gable Elasfar canals (Nile River) were collected in each month starting from March 2015 over a period of 12 months. As well as vegetables and fruit samples (lettuce, green onion and strawberry) were irrigated and washed with drainage water were also collected. Samples were extracted and concentrated for viral analysis. Strawberry and lettuce foods collected from El-Mariotia and lettuce from El-Gable Elasfar gave positive serological results by enzyme-linked immunosorbent assay (ELISA) test. Reverse transcription polymerase chain reaction (RT-PCR) was successfully used to detect the virus in strawberry and lettuce samples using HAV-specific primers, designed to amplify a 500 bp fragment covering VP1/2A gene in HAV. The VP1/2A gene was sequenced and the nucleotide sequence similarity was in the range of $95-99.1 \%$ between HAV-Eg isolate and 30 HAV sequences retrieved from GenBank. Phylogenetic analysis revealed that HAV-Eg isolate was grouped into a clade comprising Egyptian HAV isolates sub-genotype IB. Phylogenetic tree of nucleotides sequence showed that HAV sub- genotype IB is the circulating strain.

Keywords: Hepatitis A virus, Fresh foods, Cell line culture, Serological detection, RT-PCR, Sub-genotype IB.

\section{Introduction}

Hepatitis A virus (HAV) is responsible for acute infectious hepatitis, which is an important public health problem worldwide. HAV is a member of the Picornaviridae family; it is the single species in genus Hepatovirus. On the basis of genome sequence divergence, all viruses infecting humans have been classified in genotypes (I-IV), further divided into two sub-genotypes (A and B) (Costa-Mattioli et al., 2003). Genotypes and subgenotypes show different geographic distribution (Vaughan et al., 2014). Subtype IA appears to be responsible for the majority of hepatitis A cases worldwide whereas subtype IB viruses have been mainly found in the Mediterranean region (Nainan et al., 2006 and Pinto et al., 2007), although they may be reported elsewhere too (Sanchez et al., 2002). The virions are non-enveloped, with a diameter of approximately $27-32 \mathrm{~nm}$. The genome is single-stranded, linear, positive-sense RNA, approximately $7.5 \mathrm{~kb}$ in length. HAV refers to liver inflammation caused by HAV infection where is one of several viruses that can cause hepatitis. The incubation period of HAV is 2 to 6 weeks with an average of 28 days. The HAV is shed in large numbers $\left(>10^{6}\right.$ particles $\left./ g\right)$ in feces from the latter 2 weeks of the incubation period for up to 5 weeks.

Outbreaks of hepatitis A have occurred after ingestion of fecally polluted drinking or recreational water and consumption of raw or inadequately cooked polluted foods.

The major routes of food contamination include, fruits, vegetables and shellfish, which often become contaminated through contaminated water in their growing area or during preparation through contact with fecally contaminated surfaces or infected food handlers (Robertson

"Corresponding author email: drdougdoug@yahoo.com

DOI : 10.21608/ejbo.2017.1088.1099

C2017 National Information and Documentation Center (NIDOC) 
et al., 2000). Recent food-borne outbreaks of hepatitis A have been associated with different types of canned soft fruit like strawberries (Anonymous, 1997), vegetables like green onions and lettuces (Bidawid et al., 2000) and frozen berries (Bruni et al., 2016). HAV is considered one of the most common illnesses through oralfecal infection special in children and olds in poor developing country (Fan et al., 2006).

HAV antigen has been detected in stool, cell culture and environmental samples by using radioimmunoassays and enzyme immunoassays (Hollinger \& Emerson, 2001); ELISA in situ was performed to quantify the infectivity of HAV in cell culture (Costa et al., 2013). The main routine detection of HAV in food include the presence of inhibitory substances in the samples and the low concentration of virus recovered (Costa-Mattioli et al., 2002), Immunomagnetic separation (IMS) is one of the sample treatment methods that can address these limitations during using RT-PCR for detection of HAV in food (Costa-Mattioli et al., 2002 and Abd El Galil et al., 2004).

Conventional polymerase chain reaction (PCR) plays an important role in HAV detection in environmental samples (Nainan et al., 2006).

The VP1/2A junction of HAV genome had been used in characterization of strains and grouping in different genotypes (I-VII) and subgenotypes (IA, IB, IIIA, IIIB) (Nainan et al., 1991; Robertson et al., 1992 and Wang et al., 2013). Genotypes are distinguished by $15-25 \%$ sequence diversity, whereas subgenotypes in each genotype differ in about $7.5 \%$ of base positions (Robertson et al., 1992).

Recent studies have shown the predominance of genotype IB in Egypt (Pinto' et al., 2007; Kamel et al., 2011 and Hamza et al., 2017).

The aim of this study was to detect HAV by serological, molecular technique and to evaluate the possibility of rapidly and efficiently determining virus particles in both drainage water and fresh food samples. Moreover, we report the results of phylogenetic analysis of $\mathrm{HAV}-\mathrm{Eg}$ isolate based on VP1/2A region of hepatitis A sequence.

\section{Materials and Methods}

Virus sources

Two samples outlet drainage waters from ElMariotia and El-Gable Elasfar canals (Nile River) were collected at March 2015 intervals every month up to a year. Forty liters of each water sample in plastic container were obtained, forty $\mathrm{ml}$ of Aluminum chloride $(2.1 / 100 \mathrm{ml}$ water $)(\mathrm{w} / \mathrm{v})$ was added to increase the stability of the viruses in the samples during transportation according to APHA (1998).

Fresh 10 samples of each lettuce, green onion, and strawberry were irrigated with drainage water were collected in $12 / 2015$ to $4 / 2016$. Then these collected samples were washed by soaking in polluted water from El-Mariotia and El-Gable Elasfar canals (Nile River). Five kilo grams of each crop were stored in plastic bag and kept at $-20^{\circ} \mathrm{C}$ until used for extraction.

\section{Isolation of virus}

\section{Food sample extraction for viral analysis}

Fresh plant tissues $(5 \mathrm{~kg})$ were sterilized by soaking in $70 \%$ ethanol for $5 \mathrm{~min}$ then socked in $2 \%$ sodium hypochlorite for $1 \mathrm{~min}$, washed in sterilized distilled water for $2 \mathrm{~min}$ and dried. To investigate the presence of HAV in the samples, fresh plant tissues of each sample was cut and mixed in sterile distilled water and macerated using electric blender. The extraction was filtrated with two layers cheese cloth. The crude sap was clarified by filter paper (Whatman No 4) and stored at $-20^{\circ} \mathrm{C}$ until used for concentration.

\section{Concentration of virus}

Primary concentration: Viruses were eluted and concentrated from foods surface and crude sap samples via: $150 \mathrm{ml}$ of $10 \%(\mathrm{w} / \mathrm{v})$ beef extract was added to $100 \mathrm{~g}$ raw fresh foods and to 100 ml crude sap samples, the mixtures were stirred for $30 \mathrm{~min}$ at room temperature and centrifuged at $12000 \mathrm{rpm}$ for $15 \mathrm{~min}$ at room temperature (Croci et al., 2008). The pellet was discarded and the supernatant was then concentrated by organic flocculation method.

Adsorption /elution technique (APHA, 1998) was used for concentration of twenty liters of each water sample. Virus particles are negatively charged at $\mathrm{pH}$ 7.0, and for the water passing through an electron negatively charged filter nitrocellulose membranes (Schleicher and Schuell, $0.45 \mu \mathrm{m}$ pore size and $142 \mathrm{~mm}$ diameter filter series).

Secondary concentration: All samples were secondary re-concentrated using an organic flocculation method according to Katzenelson et al. (1976), Anonymous (2013) and Dietrich et al. (2013), then the elutes were acidified to $\mathrm{pH}$ 
3.5 using $\mathrm{HCl}(5 \mathrm{~N})$, (Merck-Schuchardt) and centrifuged at $3000 \mathrm{rpm}$ for $15 \mathrm{~min}$. The supernatant was discarded and the pellet was dissolved in $1 \mathrm{ml}$ of $\mathrm{Na}_{2} \mathrm{HPO}_{4}(\mathrm{El}$ Nasr Pharmaceutical Chemical Co.) $(0.14 \mathrm{~N}, \mathrm{pH} 9)$ for water samples. All samples were kept at $-70^{\circ} \mathrm{C}$ for further analysis.

\section{Enzyme-linked immunosorbent assay (ELISA)}

For immune-assay, enzyme linked imunosorbent assay was used for detection HAV in concentrated drainage water and concentrated extracts of fruit and vegetables samples as well as propagated virus (two replicates for each sample) according to Coulson \& Holmes (1984). Sterile pure tap water and healthy vegetables and fruit samples were used as negative control.

\section{Titration of HAV}

The concentrated virus from extracts of vegetables were passed on cell culture, Vero cell line, clone (CCL -81) (Yasumura \& Kawakita, 1963). Viral infectivity was measured as described, ten fold serially of concentrated virus was diluted in Eagle's minimum essential medium (MEM-E) and each dilution was dispensed to a column of 8 wells. The quantification of HAV was detected by the tissue culture infective dose (TCID50). TCID50/ml was calculated by Reed \& Muench (1938).

\section{Plaque assay of $H A V$}

Confluent monolayer of cells were prepared (Vero cell) in 6 well plates ( Serial 10-fold serial dilutions were prepared $\left(10^{1}-10^{7}\right)$ of virus in chilled maintenance medium ( (MEM-E) with $1 \%$ serum). Culture medium were removed and $0.2 \mathrm{ml}$ of virus inocula were added, starting from the highest dilution. The plates were incubated at $37^{\circ} \mathrm{C}$ for $1 \mathrm{~h}$ with intermittent rocking of the plate. The inocula were removed, preferably with a pipette and then $1.5 \mathrm{ml}$ of agarose overlay medium (growth medium were added with $1 \%$ agarose and 2\% heat-inactivated fetal calf serum (FCS)). It was left at room temperature for 10 min and then incubated it at $37^{\circ} \mathrm{C}$. The monolayer daily, were examined starting from second day of incubation. Once the plaques had developed, usually by the fourth day post inoculation, the numbers of plaques were counted at each dilution, the agarose overlay was removed and gently washed the monolayer with PBS. The plate was stained with $0.1 \%$ crystal violet solution and the plaques were counted again. The virus titer were estimated as a plaque forming units per $\mathrm{ml}$ (PFU/ml) (Lemon et al., 1991).
HAV RNA extraction, RT-PCR and sequencing

Viral RNA was extracted directly from both concentrated drainage water and concentrated extracts of fruit and vegetables samples using a QIAamp Viral RNA Mini Kit (Qiagen, Hilden, Germany), following the manufacturer's instructions. The RNA was eluted in $60 \mu \mathrm{l}$ of elution buffer and stored at $-80^{\circ} \mathrm{C}$.

HAV was detected by using the primers HAVF (5'-GGTTTCTATTCAGATTGCAAATTA-3') and HAVR (5'-AGTAAAAACTCCAGCATCCATTTC-3') (Lee et al., 2013) based on the sequence of the VP1/2A junction region of HAV genome. For reverse transcription reactions, one $\mu 1$ Omniscript Reverse Transcriptase was used to catalyze the reaction in the presence of $2 \mu \mathrm{l}$ HAVR, 10x Buffer RT ( $2 \mu 1), 2 \mu l$ dNTP Mix (5 $\mathrm{mM}$ each dNTP), $5 \mu 1$ RNA and $8 \mu 1$ nucleasefree water to final volume $20 \mu$. This reaction mix was incubated for $60 \mathrm{~min}$ at $37^{\circ} \mathrm{C}$. The RTPCR reaction mix was $25 \mu 1$ which consisted of $5 \mu \mathrm{l}$ of cDNA, $12.5 \mu \mathrm{l}$ of $2 \mathrm{X}$ GoTaq Green Master Mix (Promega, USA) to provide final concentration $1 \mathrm{X}$ with $1.5 \mathrm{mM} \mathrm{MgCl} 2$ in the final reaction volume, $0.6 \mu \mathrm{M}$ for both HAVF and HAVR primers. The RT-PCR amplification conditions were as follow: Initial denaturation step at $95^{\circ} \mathrm{C}$ for $2 \mathrm{~min}, 40$ cycles of denaturationannealing-extension at $95^{\circ} \mathrm{C}, 55^{\circ} \mathrm{C}, 72^{\circ} \mathrm{C}$ for 1 min each, respectively. Ten microliters of PCR product were analyzed by electrophoresis using $1.5 \%$ agarose gel containing $0.5 \mu \mathrm{g}$ ethidum bromide and visualized under UV light in the presence of GeneRuler 100 bp Plus DNA Ladder, ready-to-use (Thermo scientific). PCR products of HAV was excised, and subjected to gel purification using QIAquick Gel Extraction Kit (Qiagen, Hilden, Germany) according to the manufacturer's instructions. The purified PCR products of HAV were subjected for sequencing to know the circulating genotype.

\section{Sequence analysis}

Sequence of HAV was analyzed using MEGA6 program. Thirty HAV isolates retrieved from GenBank database representative HAV genotypeI sequences from VP1/2A region were used for the alignments. Phylogenetic tree was constructed by MEGA6 program using the Neighbour-Joining method and Kimura's two parameters model. Reliability of tree was estimated by using 1000 bootstrap replications (Tamura et al., 2013). 


\section{Results}

Serological detection of HAV

Enzyme-linked immunosorbent assay (ELISA) was used to detect HAV in concentrated drainage water and extracts of the fruit and vegetables. Concentrated drainage water, strawberry and lettuce fresh food samples irrigated and washed with drainage water El-Mariotia gave positive results. Moreover, lettuce washed with drainage water El-Gable Elasfar gave positive result while strawberry and green onions gave negative reaction. Positive reaction was defined if the optical density (OD) of test sample exceed that of cut off value; $\geq 0.24$ (Table 1 ).

TABLE 1. Detection of HAV in concentrated drainage water and foods by ELISA test.

\begin{tabular}{|c|c|c|c|c|c|c|c|c|}
\hline \multirow{2}{*}{$\begin{array}{l}\text { Sample } \\
\text { Test }\end{array}$} & \multicolumn{4}{|c|}{$\begin{array}{c}\text { Concentrated irrigated and washed food in } \\
\text { drainage water (El-Mariotia) }\end{array}$} & \multicolumn{4}{|c|}{$\begin{array}{l}\text { Concentrated irrigated and washed food in } \\
\text { drainage water (El-Gable Elasfar) }\end{array}$} \\
\hline & $\begin{array}{l}\text { Lettuce } \\
\text { leaves }\end{array}$ & Strawberry & $\begin{array}{l}\text { Green } \\
\text { onion }\end{array}$ & $\begin{array}{l}\text { Drainage } \\
\text { water }\end{array}$ & $\begin{array}{l}\text { Lettuce } \\
\text { leaves }\end{array}$ & Strawberry & $\begin{array}{l}\text { Green } \\
\text { onion }\end{array}$ & $\begin{array}{l}\text { Drainage } \\
\text { water }\end{array}$ \\
\hline ELISA(OD) & 0.551 & 0.502 & 0.140 & 0.675 & 0.652 & 0.101 & 0.101 & 0.725 \\
\hline
\end{tabular}

$\mathrm{OD}=$ Optical density $\quad$ Positive sample $=\geq 0.240$ (OD)

Biological properties of $H A V$

Concentrated fruit and vegetable food samples applied on Vero cell line were revealed lyses cell formed plaques after 4 days incubation period (Fig.1). HAV titer was calculated as plaque forming units (PFU/ml). It was recorded a infectivity titer in the order of $9.5 \times 10^{6}$ and $2.0 \times 10^{4} \mathrm{PFU} / \mathrm{ml}$ for lettuce and strawberry irrigated with drainage water of El-Mariotia Canal and, $9.5 \times 10^{6}$ and $1.5 \times 10^{4} \mathrm{PFU} / \mathrm{ml}$ of ElGable Elasfar, respectively.

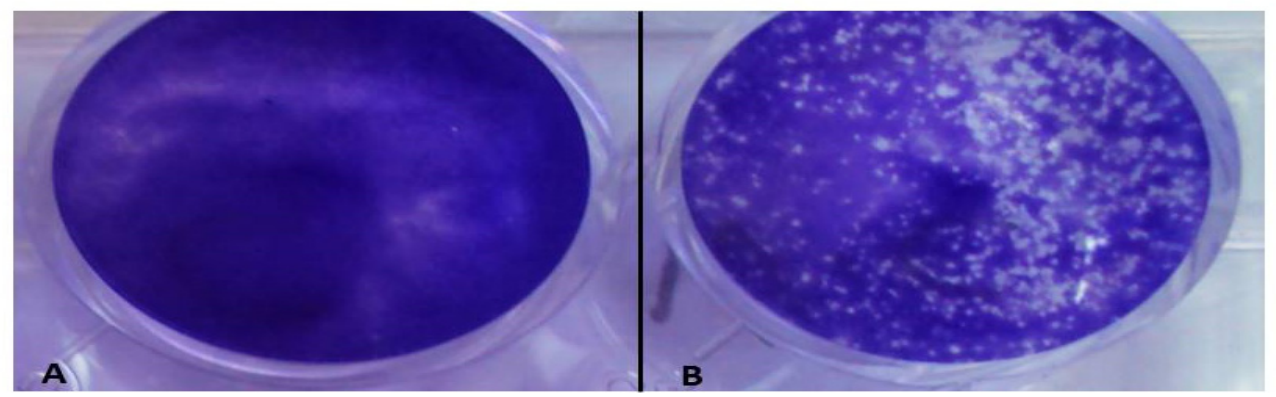

Fig.1. (A) Vero cell line culture (control) and (B) inoculated with HAV after 4 days of incubation.

Serological detection of propagated HAV in cell line

As shown in Table 2, HAV in concentrated strawberry and vegetables post propagation in Vero cell line was detected using ELISA test. Positive reaction was defined if the optical density (OD) of test sample exceed that of cut off value; $\geq 0.24$.

\section{Molecular identification of HAV}

$H A V$ cDNA synthesis and amplification

The obtained purified HAV-RNA from strawberry and lettuce sample concentrates was transcribed to cDNA then $\mathrm{VP} 1 / 2 \mathrm{~A}$ junction region of the genome was amplified by PCR. The size of PCR product was estimated by agarose gel electrophoresis comparing with standard DNA ladder (100 bp); the amplified fragment was with expected size $\approx 500 \mathrm{bp}$.

Sequence analysis

To characterize the HAV isolate detected in strawberry, PCR products from the VP1/2A junction region were sequenced and analyzed. The relationship between HAV-Eg isolate and other 30 selected HAV isolates registered in GenBank was done as illustrated in Table 3. BLAST analysis of the VP1/2A junction region showed high sequence homology to different HAV sequences from different geographic origins ranged from $95 \%$ to $99.1 \%$ 
TABLE 2. Detection of HAV in Vero cell line by ELISA test.

\begin{tabular}{|c|c|c|c|c|c|c|}
\hline \multirow[t]{2}{*}{ Sample } & \multicolumn{3}{|c|}{$\begin{array}{l}\text { Concentrated washed vegetables and fruit } \\
\text { in drainage waterEl-Mariotia }\end{array}$} & \multicolumn{3}{|c|}{$\begin{array}{l}\text { Concentrated washedvegetables and fruit } \\
\text { in drainage waterEl-Gable Elasfar }\end{array}$} \\
\hline & $\begin{array}{l}\text { Lettuce } \\
\text { leaves }\end{array}$ & Strawberry & $\begin{array}{l}\text { Green } \\
\text { onion }\end{array}$ & $\begin{array}{c}\text { Lettuce } \\
\text { leaves }\end{array}$ & Strawberry & Green onion \\
\hline ELISA (OD) & 0.652 & 0.601 & 0.101 & 0.551 & 0.502 & 0.140 \\
\hline
\end{tabular}

$\mathrm{OD}=$ Optical density Positive sample $=\geq 0.240(\mathrm{OD})$.

TABLE 3. Identity percentage of nucleotide sequence of VP1/2A region for HAV-Eg isolate and 30 other HAV isolates retrieved from GenBank database.

\begin{tabular}{|c|c|c|c|}
\hline $\begin{array}{l}\text { Accession No. / } \\
\text { isolate }\end{array}$ & $\begin{array}{c}\text { Identity } \\
\text { percentage }\end{array}$ & HAV strain & Country \\
\hline HAV-Eg & 100.00 & HAV-Eg-2016 & Egypt \\
\hline KX228687 & 99.10 & HAV/Egy/ST-NO-1/2015 & Egypt \\
\hline KX228685 & 98.88 & HAV/Egy/ZI-6/2015 & Egypt \\
\hline KX228684 & 98.88 & HAV/Egy/BI-3/2015 & Egypt \\
\hline KX228694 & 98.65 & HAV/Egy/BI-11/2015 & Egypt \\
\hline KX228682 & 98.86 & HAV/Egy/EI-11/2015 & Egypt \\
\hline KX228693 & 99.01 & HAV/Egy/BI-2/2015 & Egypt \\
\hline KX228690 & 98.98 & HAV/Egy/EI-9/2015 & Egypt \\
\hline KU570242 & 98.33 & ISS-022 & Italy \\
\hline KU570257 & 98.31 & UNIMI-005 & Italy \\
\hline KU570241 & 98.12 & ISS-021 & Italy \\
\hline LC035019 & 97.77 & 1403-15617-TMUH-4HA28N & Japan \\
\hline KJ436959 & 97.66 & SEWAGE/NL/2011-024-17 & The Netherlands \\
\hline AY294047 & 97.53 & IT-MAR-02 & Italy \\
\hline KJ436970 & 97.19 & SEWAGE/NL/2011-024-13 & The Netherlands \\
\hline KY003229 & 97.08 & 20160920 & United Kingdom \\
\hline KJ436973 & 96.96 & SEWAGE/NL/2011-024-10 & The Netherlands \\
\hline M14707 & 96.43 & HM-175 & Australia \\
\hline KX343014 & 96.43 & HM175 & USA \\
\hline KX035096 & 95.76 & $18 \mathrm{f} .1$ & USA \\
\hline KP879216 & 95.76 & $18 \mathrm{f}$ & USA \\
\hline KF724020 & 95.76 & F0.2A & Spain \\
\hline KF569906 & 95.76 & DH01 & China \\
\hline M59808 & 95.76 & HM175/18f (clone B) & USA \\
\hline AJ505564 & 95.54 & IT-COL-00 & Italy \\
\hline HG798854 & 95.54 & HAV41_2013 & Spain \\
\hline HG798830 & 95.54 & HAV14_2012 & Spain \\
\hline AF314208 & 95.54 & L-A-1 & China \\
\hline HG798835 & 95.31 & HAV20_2012 & Spain \\
\hline EF406360 & 95.09 & $\mathrm{H} 2 \mathrm{~K} 15$ & China \\
\hline EF406359 & 95.09 & $\mathrm{H} 2 \mathrm{~K} 10$ & China \\
\hline
\end{tabular}




\section{Phylogenetic analysis}

The VP1/2A region nucleotide sequence from the HAV-Eg isolate and 30 isolates from different parts of the world were aligned and a phylogenetic tree was constructed (Fig. 2). Phylogenetic analysis revealed that HAV-Eg isolate was correlated to HAV Egyptian isolate (accession no. KX228687) genotype I, sub-genotype IB which grouped into a distinct clade comprising Egyptian HAV isolates sub-genotype IB.

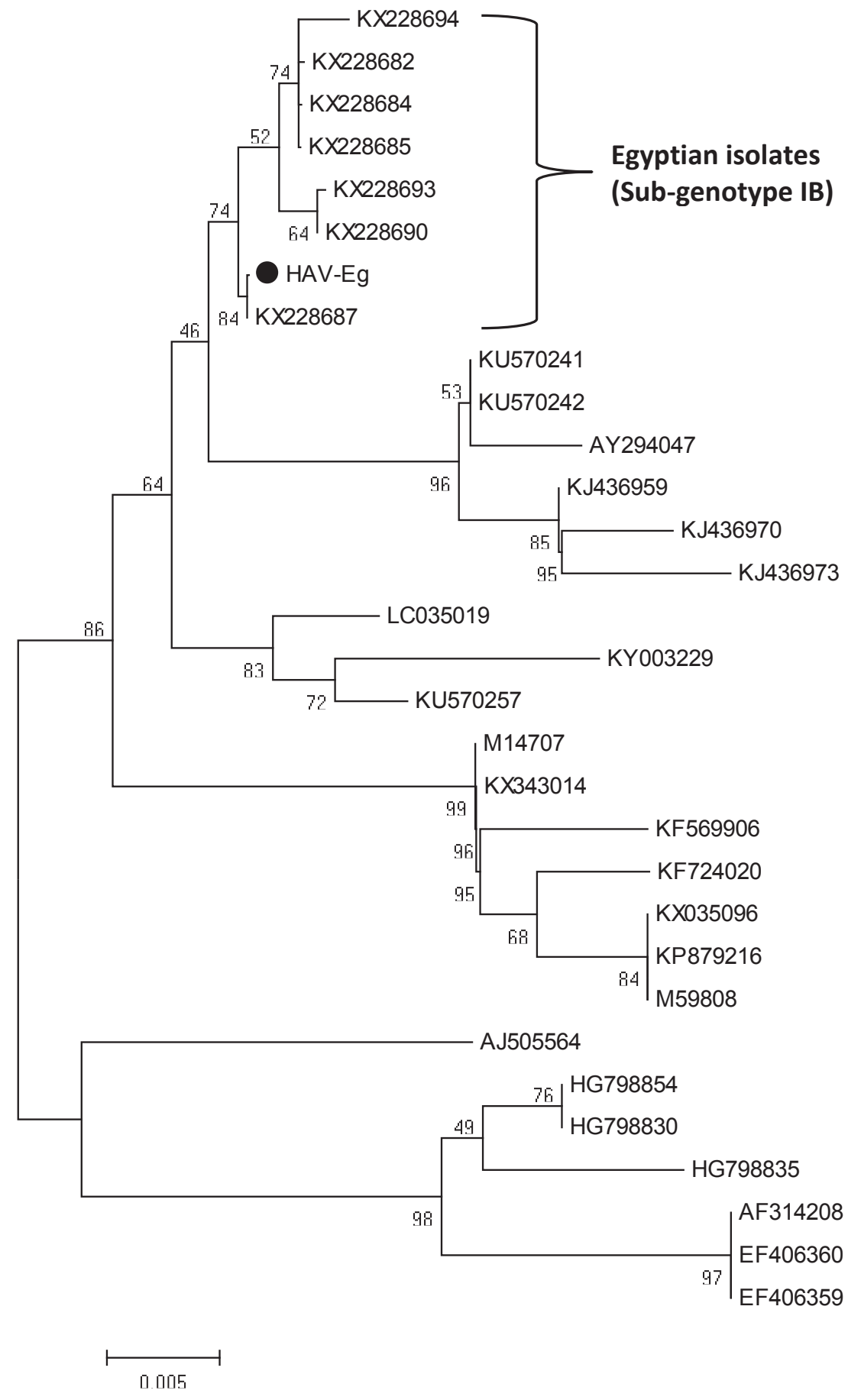

Fig. 2. Phylogenetic tree of the VP1/2A region of hepatitis A sequence isolated in the present study (is marked with dot) and sequences obtained from GenBank. Neighbour-joining tree was built with the program MEGA6, The evolutionary distances were computed using the two-parameter model of Kimura. The numbers on the branches show bootstrap percentages obtained after 1000 replicates of bootstrapping sampling. The length of bars shows the distances. 


\section{Discussion}

The development of sensitive diagnostic assay is of the utmost importance for diagnosing and monitoring HAV contaminated drainage water and vegetables and the efficiency of diagnosis allows for proper precautions to be taken to prevent and minimize HAV spreads.

In Egypt outbreaks of hepatitis were appeared among European travelers who visited the country between November 2012 and April 2013 and 89 probable cases have been reported as well as other outbreaks that were reported earlier (Frank et al., 2007 and Sane et al., 2015). The outbreak in Czech Republic was associated with frozen products made of imported strawberries watered with sewage (Votava et al., 2003). Washing of contaminated fresh vegetables does not guarantee elimination of viral particles (Croci et al., 2002).

In this study, ELISA test gave positive results in some vegetables and fruit samples (Vasickova et al., 2005).Various immunoassays such radioimmunoassays (RIA) and ELISA are commonly used as for diagnostic of HAV infected samples. ELISA have the advantage of given numerical result which can be objectively interpreted but they require multiple steps in processing and usually are not cost effective for testing small number of specimens (Beards et al., 1984 and Thomas et al., 1988).

Initially RT-PCR was used for detection of HAV in concentrated drainage water and fresh vegetables. RT-PCR can detect a fragment of HAV RNA in strawberry and lettuce samples under study. RT-PCR provides an extremely sensitive and rapid procedure that contributes to improve laboratory diagnosis of HAV (Love et al., 2008). The positive samples which identified by RT-PCR importantly showed no false-negative result since none of the samples was positive by ELISA and negative RT-PCR (Nashwa \& Ahmed, 2014).

The RT-PCR reduces the risk of cross contaminated and so has been described as a high sensitive quantitative detected method for viral nucleic acids ( $\mathrm{Li}$ et al., 2010).

Virus isolation is considered one of the methods for HAV diagnosis. However, it requires fully equipped laboratories with skilled professionals and has along turn around time. Additionally, HAV tends to be labile and loss of infectivity can occur during transport. Many studies have reported that nucleic acid amplification technique are more sensitive than viral culture for detecting HAV in samples (Chigor \& Okoh, 2012). This may be explained at least in part by non-viability of viral particles in the specimens that can be detect by RT-PCR was used for HAV detection. The results showed of the concentrated drainage water, strawberry and lettuce samples were positive for HAV-RNA by RT-PCR while were positive for HAV antigen by ELISA test with sensitive and specificity, after HAV propagated in cell line culture our result was in accordance with result obtained by Costa et al. (2013).

Several studies were conducted in Egypt and their results showed higher or lower frequencies of HAV detection, Hasan (2015) detected HAV infection using RT-PCR in samples collected from drains water and vegetables.

HAV was visualized in fecal extracts by electron microscopy using homologous antiserum (Feinstone et al., 1973), but also RIA or ELISA are readily employed for clinical diagnosis. However, the sensitivity of these procedures is not high enough to detect the low number of viral particles sometimes present in the environment. In the case of environmental samples, amplification of viral nucleic acids by polymerase chain reaction (PCR) assays coupled to reverse transcription (RT-PCR) has been used in water and shellfish. (Vasickova et al., 2005 and Bruni et al., 2016).

The molecular characterization is as an essential tool to trace HAV outbreaks (Bruni et al., 2016); mixed frozen berries were early demonstrated to be the source of HAV infection by the identity of viral sequences in patients and in food.

Both strawberry and lettuce irrigated or washed with drainage water previously diagnosed as HAV positive, using primer set spanning the sequence of VP1/2A junction region resulting $500 \mathrm{bp}$ PCR products. RT-PCR was performed using undiluted RNA preparations suggesting the efficient removal of PCR inhibitors. The detection of HAV may represent a threat of accidental contamination of the water system and support the probability of circulating of HAV among individuals and in the environment.

Previous studies were conducted to evaluate HAV circulation in the Egyptian environment (Kamel et al., 2011 and Hamza et al., 2017). Molecular characterization of HAV is important for understanding its circulation pattern and evolutionary relationships. In this study, PCR product of HAV was purified and subjected to 
sequence analysis. Subsequently, phylogenetic tree analysis using MEGA6 software (Tamura et al., 2013) revealed the high degree of nucleotide sequence similarity with HAVsubgenotypes IB (HAV/Egy/ST-NO-1/2015) KX228687, wild-type (HM-175) M14707and(IT-COL-00) AJ505564 with 99.10,96.43 and 95.54\%, respectively (Cohen et al., 1987; Chironna et al., 2004 and Hamza et al., 2017 ). Previous studies were confirmed our data that genotype IB is the predominant genotype circulating in Egypt and North Africa (Robertson et al., 1992; Cristina \& Costa-Mattioli, 2007 and Hamza et al., 2017). Furthermore, Hamza et al. (2017) demonstrated the VP1/2A nucleotide sequences of all Egyptian isolates were 99.7\% identical to each other and 96.4 to $97.6 \%$ identical to strains of the IB genotype.

Based on the current results, it could be concluded that RT-PCR could be used as sensitive tool for confirmation of HAV detection from drainage water, fruit and vegetables concentrates. ELISA test is somewhat poorly sensitive compared with RT-PCR for detection of HAV and the predominantly circulating HAV in Egypt belongs to IB genotype.

\section{References}

Abd El Galil, K.H., El Sokkary, M.A., Kheira, S.M., Salazar, A.M., Yates, M.V., Chen, W. and Mulchandani, A. (2004) Combined immunomagnetic separation-molecular beaconreverse transcription-PCR assay for detection of hepatitis A virus from environmental samples. Applied and Environmental Microbiology, 70, 4371-4374.

Anonymous (1997) Hepatitis A associated with consumption of frozen strawberries. Morbidity and Mortality Weekly Report, 46, 288-289.

Anonymous (2013) Microbiology of food and animal feed: Horizontal method for detection of hepatitis A virus and norovirus in food using real-time RT-PCR: Part 2: Method for qualitative detection Geneva: ISO/TS 15216-2.

APHA (American Public Health Association) (1998) "Standard Methods".20 $0^{\text {th }}$ ed., American Public Health Association, Washington,D.C.

Beards, G.M., Campbell, A.D., Cottrell, N.R., Peiris, J.S., Rees N., Standers R.C, Shirley, J.A, Wood H.C., and Flewett T.H. (1984) Enzyme-linked immunosorbent assay based on polyclonal and monoclonal antibodies for Rotavirus detection. Journal Clinical Microbiology, 19, 248-254.
Bidawid, S., Farber, J.M., Sattar, S.A. (2000) Rapid concentration and detection of hepatitis A virus from lettuce and strawberries. Journal of Virological Methods, 88,175-185.

Bruni, R., Taffon, S., Equestre, M., Chionne, P., Madonna, E. and Rizzo, C., et al. (2016) Key role of sequencing to trace hepatitis $\mathrm{A}$ viruses circulating in Italy during a large multi-country European foodborne outbreak in 2013. PLoS ONE, 11(2), e0149642.

Chigor, V.N., and Okoh, A.I. (2012) Quantitative RTPCR detection of hepatitis A virus, rotaviruses and enteroviruses in the Buffalo River and source water dams in the Eastern Cape Province of South Africa. International Journal of Environmental Research and Public Health, 9, 4017-4032.

Chironna, M., Lopalco, P., Prato, R., Germinario, C., Barbuti, S. and Quarto, M. (2004) Outbreak of infection with hepatitis A virus (HAV) associated with a foodhandler and confirmed by sequence analysis reveals a new HAV genotype IB variant. Journal of Clinical Microbiology, 42, 2825-2828.

Cohen, J.I., Ticehurst, J.R., Purcell, R.H., Buckler-White A. and Baroudy, B.M. (1987) Complete nucleotide sequence of wild-type hepatitis A virus: comparison with different strains of hepatitis A virus and other Picorna viruses. Journal of Virology, 61, 50-59.

Costa, A.M., Amado, L.A. and Paula, V.S. (2013) Detection of replication-defective hepatitis A virus based on the correlation between real-time polymerase chain reaction and ELISA in situ results. Memórias do Instituto Oswaldo Cruz, 108, $36-40$.

Costa-Mattioli, M., Di Napoli, A., Ferré, V., Billaudel, S., Perez-Bercoff, R. and Cristina, J. (2003) Genetic variability of hepatitis A virus. Journal of General Virology, 84, 3191-201. PMID: 14645901.

Costa-Mattioli, M., Monpoeho, S., Nicand, E., Aleman, M.H., Billaudel, S. and Ferre, V. (2002) Quantification and duration of viraemia during hepatitis A infection as determined by real-time RT-PCR. Journal of Viral Hepatitis, 9, 101-106.

Coulson, B.S. and Holmes, I.H. (1984) An improved enzyme-linked immunosorbent assay for the detection of rotavirus in faeces of neonates. Journal Virology Methods, 8, 165-179.

Cristina, J. and Costa-Mattioli, M. (2007) Genetic variability and molecular evolution of hepatitis A virus. Virus Research, 127, 151-157.

Croci, L., De Medici, D., Scalfaro, C., Fiore, A. and Toti, L. (2002) The survival of Hepatitis A virus in fresh produce. International Journal of Food Microbiology, 73, 29-34. 
Croci, L., Dubois, E., Cook, N., de Medici, D., Schultz, A., China, B., Rutjes, S., Hoorfar, J. and Van der Poel, W.H.M. (2008) Current methods for extraction and concentration of enteric viruses from fresh fruit and vegetables: towards international standards. Food Analytical Methods, 1, 73-84.

Dietrich, M., Katja, T., Eckehard, N., Marina, H., and Reimar, J. (2013) Detection and typing of norovirus from frozen strawberries involved in a large-scale gastroenteritis outbreak in Germany. Food and Environmental Virology, 5,162-168.

Fan, D., Wang, C., Zhang, Y., Li, X. and Wang, X. (2006) The seroepidemiological investigation of HAV among the population aged from 1 to 15 years in HAV outbreak area in Yili Prefecture. Disease Surveill, 21(10), 526-528.

Feinstone, S.M., Kapikian A.Z., Purcell, R.H. (1973) Hepatitis A: detection by immune electron microscopy of a virus-like antigen associated with acute illness. Science, 182,1026-1028.

Frank, C., Walter, J., Muehlen, M., Jansen, A., van Treeck, U., Hauri, A.M., Zoellner, I., Rakha, M., Hoehne, M., Hamouda, O., Schreier, E. and Stark, K., (2007) Major outbreak of hepatitis A associated with orange juice among tourists, Egypt, 2004. Emerging Infectious Diseases, 13, 156-158.

Hamza, H., Abd-Elshafy, D.N., Fayed, S.A., Bahgat, M.M., El-Esnawy, N.A. and Abdel-Mobdy, E. (2017) Detection and characterization of hepatitis A virus circulating in Egypt. Archives of Virology, 1-11 doi: 10.1007/s00705-017-3294-4.

Hasan, S.F. (2015) Development of real-time reverse transcription polymerase chain reaction methods for quantitative of enteric viruses in some raw vegetable and irrigation water samples. M.Sc. Thesis, Fac. Sci., AL-Azhar Univ., Girls.

Hollinger, F.B. and Emerson, S.U. (2001) Hepatitis A virus, In: "Fields Virology" D. M. Knipe and P. M. Howley (Ed.), , 4 ${ }^{\text {th }}$ ed. pp.799-840, Lippincott Williams \& Wilkins, New York, N.Y.

Kamel, A.H., Ali, M.A., El-Nady, H.G., Deraz, A., Aho, S., Pothier, P. and Belliot, G. (2011) Presence of enteric hepatitis viruses in the sewage and population of Greater Cairo. Clinical Microbiology and Infection, 17, 1182-1185.

Katzenelson, E., Fattal, B. and Hostovesky, T. (1976) Organic flocculation: an efficient secondstep concentration method for the detection of viruses in tap water. Applied and Environmental Microbiology, 32, 838-839.
Lee, A.R., Lee, S.G., Kang, L.H., Jheong, W.H. and Paik, S.Y. (2013) Full length genomic sequence of subgenotype IIIA hepatitis A virus isolate in Republic of Korea. BioMed Research International 2013:11. doi: $10.1155 / 2013 / 426034$

Lemon, S.M., Murphy, P.C., Shields, P.A., Ping, L.H., Feinstone, S.M., Cromeans, T. and Jansen, R.W. (1991) Antigenic and genetic variation in cytopathic hepatitis A virus variants arisingduring persistent infection: evidence for genetic recombination. Journal of Virology, 65, 2056-2065.

Li, P.S., Paniconi, M., Auricchio, B., Orefice, L., Schultz, A.C., et al. (2010) Comparison of different concentration methods for the detection of hepatitis A virus and calicivirus from bottled natural mineral waters. Journal of Virological Methods, 165, 57-63.

Love, D.C., Casteel, M.J., Meschke, J.S. and Sobsey, M.D. (2008) Methods for recovery of hepatitis A virus (HAV) and other viruses from processed foods and detection of HAV by nested RT-PCR and TaqMan RT-PCR. International Journal of Food Microbiology, 126, 221-226

Nainan, O.V., Margolis, H.S., Robertson, B.H., Balayan, M. and Brinton, M.A. (1991) Sequence analysis of a new hepatitis A virus naturally infecting cynomolgus macaques (Macaca fascicularis). Journal of General Virology, 72,1685-1689.

Nainan, O.V., Xia, G., Vaughan, G. and Margolis, H.S. (2006) Diagnosis of hepatitis A virus infection: A molecular approach. Clinical Microbiology Reviews, 19, 63-79.

Nashwa, M.H. and Ahmed, S.A. (2014) Serological and Molecular diagnosis of FMD virus in Sharkia and Fayoum governorates. Egyptian Journal of Virology, 11(1),168-175.

Pinto', R.M., Alegre, D., Dominguez, A., El-Senousy, W.M., Sanchez, G., Villena, C., Costafreda, M.I., Aragones, L. and Bosch, A. (2007) HepatitisA virus in urban sewage from two Mediterranean countries. Epidemiology and Infection, 135, 270-273.

Reed, L.J. and Muench, H. (1938) A simple method of Estimating fifty percent endpoint. The American Journal of Hygiene, 27, 493-497.

Robertson, B.H., Averhoff, F., Cromeans, T., Han, X., Khoprasert, B., Nainan, O.V., et al. (2000)Genetic relatedness of hepatitis A virus isolates during a community-wide outbreak. Journal of Medical Virology, 62(2), 144-150.

Robertson, B.H., Jansen, R.W., Khanna, B., Totsuka, A., Nainan, O.V., Siegl, G., Widell, A., Margolis, 
H.S., Isomura, S., Ito, K., Ishizu, T., Moritsugu ,Y. and Lemon, S.M. (1992) Genetic relatedness of hepatitis A virus strains recovered from different geographical regions. Journal of General Virology, 73, 1365-1377.

Sanchez, G., Pinto, R.M., Vanaclocha, H., Bosch, A. (2002) Molecular characterization of hepatitis a virus isolates from a transcontinental shellfishborne outbreak. Journal of Clinical Microbiology, 40, 4148-4155.

Sane, J., MacDonald, E., Vold, L., Gossner, C. and Severi, E. (2015) Multistate foodborne hepatitis A outbreak among European tourists returning from Egypt - need for reinforced vaccination recommendations, November 2012 to April 2013. Euro Surveillance, 20, 210-217

Tamura, K., Stecher, G., Peterson, D., Filipski, A. and Kumar, S. (2013) MEGA6: Molecular Evolutionary Genetics Analysis version 6.0. Molecular Biology and Evolution, 30, 2725-2729.

Thomas, E.E., Puterman, M.L., Kawano, E. and Curran, M. (1988) Evaluation of seven immunoassay for detection of Rotavirus in pediatrict stool samples.
Journal Clinical Microbiology, 26,1189-1193.

Vasickova, P., Dvorska, L., Lorencova, A., Pavlik, I. (2005) Viruses as a cause of foodborne diseases. Veterinarni Medicina, 50, 89-104.

Vaughan, G., Goncalves, Rossi, L.M., Forbi, J.C., de Paula, V.S., Purdy, M.A., Xia, G. et al. (2014) Hepatitis A virus: host interactions, molecular epidemiology and evolution. Infection, Genetics and Evolution 21:227-243. doi: 10.1016/j. meegid..10.023 Review. PMID: 24200587

Votava, M., Cerhnohorska, L., Heroldova, M., Hola, V., Mejzlikova, L., Ondrovcik, P., Ruzicka, F., Dvorackova, M., Woznicova, V. and Zahradnicek, O. (2003) "Special Medical Microbiology" (in Czech). Neptun, Brno. pp. 237-365.

Wang, H., Zheng, H., Cao, J., Zhou, W., Yi, Y., Jia, Z., et al. (2013) Genetic diversity of hepatitis A virus in China: VP3-VP1-2A genes and evidence of Quasispecies distribution in the isolates. PLOS ONE, 8(9), e74752. doi:10.1371/journal.pone.0074752

Yasumura, Y. and Kawakita, Y. (1963) Studies on SV40 in tissue culture-preliminary step for cancer research "in vitro". Nihon Rinsho, 21, 1 201-1215.

(Received 13 / 5 / 2017 ; acecpted $16 / 9 / 2017$ ) 


\section{رصد تفشى فيروس التهاب الكبد الوبائى (A) فى الاغذيه الطازجه}

خالا عبدالفتاح الاجدج ، محمد عاطف نصر الدين" ، هبه سامى عيسوى" ، محمود مصطفى عامر * و مى عبدالرحيم"

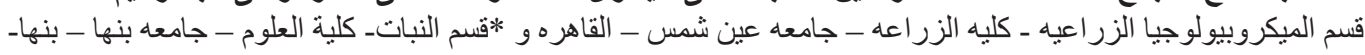

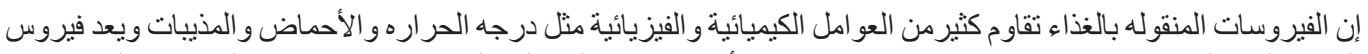

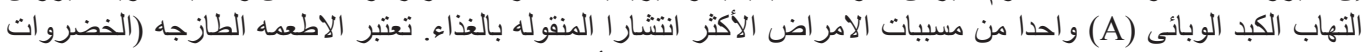

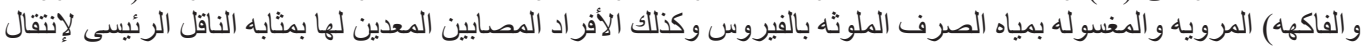

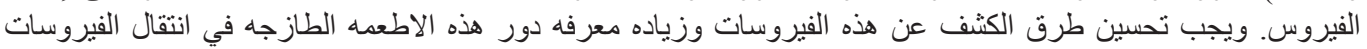

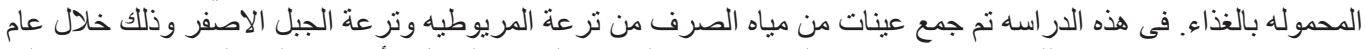

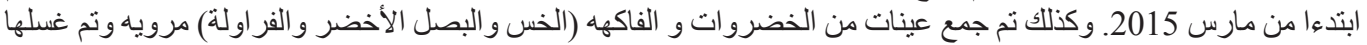

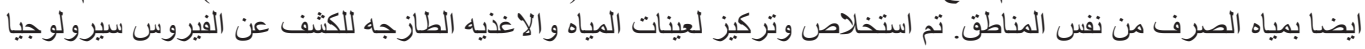
باختبار الفحص المناعي المرتبط بالإنزيم (ELISA) و ايضا باستخدام تفاعل إنزيم البلمرة المتسلسل العكسى (RT-PCR). أعطت عينات الفراولة والخس التي نم جمعها من المريوطية والخس من الجبل الأصفر نتائج إيجابية عن طريق

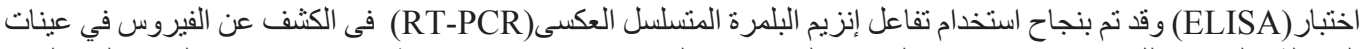

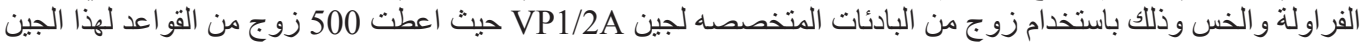

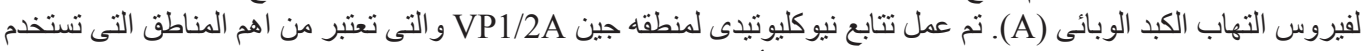

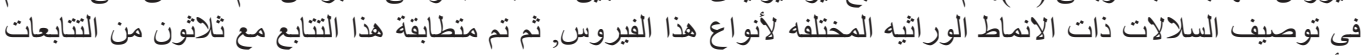

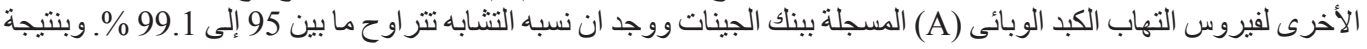

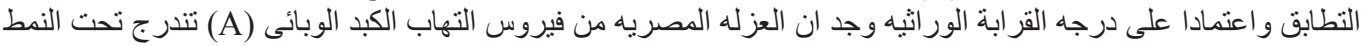

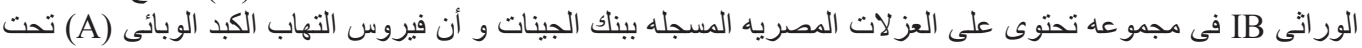
النمط الور اثى IB هو المنتشر في مصر. 